leen paljon kannatusta, minkä tähden poliittinen eliitti kiinnittää puheissaan niin paljon huomiota "oikean" islamin puolustamiseen.

\section{In memoriam Sonja Luehrmann (1975-2019)}

Konferenssin jälkeen elokuussa vastaanotimme järkyttyneinä suruviestin arvostetun ja rakkaan kollegan, antropologi Sonja Luehrmannin poismenosta. Hän osallistui EASR:n konferenssiin vajaat kahta kuukautta ennen kuolemaansa Vancouverissa 44 vuoden iässä. Sonja osallistui aktiivisesti koko konferenssiin, ja niin kuin Irina Pärt yhteistä Peipsijärven retkeä muistellessaan kirjoitti: Sonja oli täysin tyyni - kanssamme, mutta poissaoleva. Vancouverin kollegat muistelivat hänen sanojaan: "Jos minulla on enää kaksi vuotta elinaikaa, haluan elää ne antropologina”. Viimeisillä pitämillään luennoillaan hän oli pahoitellut, ettei kemoterapian aiheuttaman hajamielisyyden tähden voinut vastata opiskelijoiden kysymyksiin niin täydellisesti kuin olisi halunnut.

Professori Luehrmann oli säteilevä, antaumuksellinen ja sydämellinen. Lahjakkaalla tutkijalla oli ihmeellisellä tavalla aikaa keskustella ja osallistua kuuntelijana toisten esityksiin, myös meidän sessioomme. Tarton KGB-museon vieraskirjaan hän jätti nimikirjoituksena ja tervehdyksensä. "Toivon, että tällainen joskus avattaisiin Moskovassakin", hän sanoi.

Sonja Luehrmann oli maailman luokan tutkija, joka tunnettiin useissa verkostoissa, mm. Katja Tolstajan kokoaman INaSEc:n (Vrije Universiteit Amsterdam) holokaustin ja gulagin muistiperinnön verkostossa. Hän työskenteli myös Helsingin yliopiston tutkijakollegiumissa. Yksi perheen kolmesta lapsesta syntyi Naistenklinikalla, mistä jäi lämpimät muistot. Perhe oli monesti mukana konferensseissa, ja äiti saattoi tauolla käväistä imettämässä. Luehrmann kirjoitti viime vuosina paljon Venäjästä, mm. maallisten neuvostoarkistojen arvosta uskonnon tutkimuksen lähteenä. Hänen viimeinen kirjansa abortinvastaisesta aktivismista Venäjän ortodoksikirkossa jäi viimeistelemättä. Jäämme kaipaamaan Sonjaa, joka nyt on poissa, mutta kanssamme.

Lue Sonja Luehrmannin kotiyliopiston Simon Fraser University (Kanada) muistokirjoitus: http://www.sfu.ca/sociology-anthropology/ news-events/news-2019/in-memoriam-sonjaluehrmann.html.

Elina Kahla, Maija Penttilä ja Kaarina Aitamurto

\title{
Idäntutkimus 2020-2021: Kutsu kirjoittajille
}

Haluaisitko kirjoittaa Idäntutkimukseen? Vuosina 2020-2021 on tiedossa jälleen kiinnostavia teemoja eri aihealueilta sekä yksi numero, jossa teema on vapaa.

1/2020 Vapaa teema, deadline 15.11.2019

Vapaan teeman numeroon voi tarjota kirjoituksia Idäntutkimuksen maantieteellisesti kattamaan alueeseen liittyen eri tutkimusaloilta.

\section{2/2020 Ympäristö, deadline 1.2.2019}

Ympäristön yhteiskunnallinen ja kulttuurinen merkitys ei ole kadonnut teollistumisesta ja digitalisoitumisesta huolimatta. Itä-Euroopan tapauksessa ympäristö on usein esitetty suoraviivaisesti sosialismin aikaisen saastumisen tai sen jälkeisen jälleenrakennuksen yhteydessä, mutta uudemmissa tulkinnoissa yksipuolisia mielikuvia on alettu myös kyseenalaistaa. Samaan aikaa ilmastonmuutos ja sen hillitsemisen edellyttämät toimet ovat nostaneet esiin tarpeen uudenlaiselle ympäristöpolitiikalle ja - käsityksille. Miten ympäristö esitetään poliittisissa ja kulttuurisissa tulkinnoissa itäisen Euroopan maissa? Millaisia uusia aiheita on noussut keskusteluun? Mikä rooli esimerkiksi ympäristöaktivismilla on? Ympäristö-teemanumeroon voi tarjota artikkeleita, esseitä, kolumneja ja muita Idäntutkimukseen sopivia kirjoituksia näistä teemoista. Tarjoa tekstiäsi Ympäristö-numeron vastaavalle toimittajalle Emma Hakalalle [at] fiia.fi tai päätoimittaja Katja Lehtisaarelle.

\section{3/2020 Keho, deadline 15.4.2020}

Käsitteleekö Venäjään tai itäiseen Eurooppaan liittyvä tutkimuksesi ruumiillisuutta, terveyttä, sairautta, kehon palvontaa ja ulkonäköä tai seksuaalisuutta? Tai onko tutkimuksesi keskiössä liike ja liikkuminen tai urheilu? Oletko teatterin tai muiden esittävien taiteiden asiantuntija? Keho-teemanumerossamme muun muassa näitä kysymyksiä voi lähestyä eri tieteenalojen ja metodien näkökulmasta. 
4/2020 Uho, deadline 15.8.2020

Mahtailu, rehvakkuus, kiihko. Muun muassa näitä merkityksiä liittyy uhoon, joka on vuoden 2020 neljännen teemanumeron aihe. Teemanumeroon sopii mukaan muun muassa suurvaltapolitiikkaa, kilpavarustelua, yhteiskunnallisia liikkeitä, vastarintaa ja aktivismia käsittelevä tutkimus. Myös esimerkiksi kilpailut ja palkinnot, samoin erilaiset ismit ja ideologiat sekä manifestit voivat olla tarkastelun kohteena. Numeroon voi tarjota niin historiaa kuin nykypäivää koskevaa tutkimusta eri aloilta, kunhan aihe liittyy Venäjään tai itäiseen Eurooppaan.

Tiedossa on myös jo vuoden 2021 ensimmäinen teemanumero:

1/2021, Pohjoinen kirjallisuus, deadline 15.11.2020

Teemanumero nostaa esiin Venäjän pohjoisten alueiden äänen, niiden oman kirjallisuuden ja kulttuurin, jotka keskusteluissa arktisista alueista usein jäävät vähemmälle huomiolle kuin ympäristökysymykset ja geopoliittinen valtapeli. Millä tavoin pohjoinen kirjallisuus käsittelee modernisaatioprosesseja sekä niiden vaikutusta luontoon ja alkuperäiskansoihin? Millainen on alueen alkuperäiskansojen ja venäläisen kirjallisuuden suhde? Miten arktisen alueen kirjailijat ovat käsitelleet pohjoisen suhdetta (neuvosto) valtioon, ja miten he käsittelevät Venäjän nykytilannetta? Entä millaisena näyttäytyy urbaani pohjoinen ennen ja nyt? Teemanumeroon toivotaan kirjoitusehdotuksia, joissa käsitellään Venäjän pohjoisten alueiden kirjallisuutta ja kulttuuria. Lähetä juttuehdotuksesi teemanumeron vierailevalle toimittajalle Tintti Klapurille [at] helsinki.fi tai päätoimittaja Katja Lehtisaarelle.

Kaikkia numeroitamme koskevat kirjoitusohjeet löytyvät sivuiltamme journal.fi/idantutkimus. Tervetuloa tarjoamaan juttuideoita! Julkaisemme muun muassa tieteellisiä artikkeleita, esseitä, kolumneja, väitöslektioita, kirja-arvioita, seminaariraportteja ja keskustelunavauksia. Pyydämme jättämään valmiit artikkelikäsikirjoitukset Journal.fi-sivuston kautta; juttuideoista keskustellaksesi ota yhteyttä päätoimittaja Katja Lehtisaareen [at] helsinki.fi, toimituskunnan jäseniin tai teemanumeroiden toimittajiin. 